$\begin{array}{ll}\text { Volume } & : 06 \\ \text { Nomor } & : 02 \\ \text { Bulan } & : \text { Mei } \\ \text { Tahun } & : 2020 \\ \text { http } & : / / \text { ejurnal.pps.ung.ac.id/index.php/AKSARA/index }\end{array}$

\title{
Peran Wali Kelas Dalam Pengelolaan Anak Berkebutuhan Khusus di SDN 1 Banda Aceh
}

\author{
T. M. Haekal \\ Fakultas Tarbiyah dan Keguruan UIN AR-Raniry Banda Aceh \\ Email: tmhaekal.th@gmail.com
}

Received: 23 Februari 2020; Revised: 27 April 2020; Accepted: 28 April 2020

DOI: http://dx.doi.org/10.37905/aksara.6.2.203-212.2020

\begin{abstract}
ABSTRAK
Anak berkebutuhan khusus membutuhkan pendampingan khusus dari pihak sekolah tidak terkecuali wali kelas. Di SDN 1 Banda Aceh anak berkebutuhan khusus dikelola sesuai dengan standar yang berlaku. Penelitian ini bertujuan untuk mengetahui peran, strategi serta hambatan wali kelas dalam pengelolaan anak berkebutuhan khusus di SDN 1 Banda Aceh. Penelitian ini merupakan penelitian kualitatif dengan teknik pengumpulan data yaitu: observasi, wawancara, dan dokumentasi. Analisis dilakukan dengan teknik miles dan huberman. Hasil penelitian meliputi: 1). Peran wali kelas yaitu sangatlah dibutuhkan bahkan sangat penting dari sisi pengelolaan ABK. Sebagaimana hak wali kelas dalam mengelola anak didiknya di dalam kelas, perannya antara lain yaitu membuat RPP, merancang silabus, media, dan kurikulum modifikasi. 2). Wali kelas dalam pengelolaan anak berkebutuhan khusus adalah wali kelas dan guru pendamping khusus selalu mendampingi siswa reguler maupun anak berkebutuhan khusus selama proses belajar berlangsung sampai pembelajaran tersebut selesai, suasana kelas dibuat selalu menyenangkan terkadang ada juga siswa yang bosan sehingga guru menjadi lebih aktif menjaga. Wali kelas memahami pengelolaan tidak hanya secara teori akan memakai naluri sendiri. Hambatan yaitu kurangnya skill dalam menggali anak berkebutuhan khusus karena tenaga kependidikan bukan lulusan dari sekolah untuk anak berkebutuhan khusus. Pengelolaan anak berkebutuhan khusus yang dilakukan oleh guru di SDN 1 Banda Aceh, pengelolaan dapat dilakukan dengan baik, terbukti dengan siswa selalu berperan aktif dalam pembelajaran dan siswa mampu melaksanakan evaluasi yang dilakukan oleh guru. Dan bagi peneliti selanjutnya, semoga dapat mengkaji lebih dalam lagi mengenai pengelolaan wali kelas dan guru pendamping khusus dalam mengelola dan menangani anak berkebutuhan khusus (ABK) dan faktor-faktor yang mempengaruhi hambatan untuk lebih melengkapi dan menyempurnakan penelitian ini.
\end{abstract}

Kata Kunci: Peran Wali Kelas, Pengelolaan, Anak Berkebutuhan Khusus (ABK).

\begin{abstract}
The child with special needed need special assistance from the school side, the homeroom teacher is no exception. At Banda Aceh 1 Elementary School, children with special needs are managed in accordance with applicable standards. This study aims to determine the role, strategies and obstacles of homerooms in the management of children with special needs at SDN 1 Banda Aceh. This research is a qualitative research with data collection techniques, namely: observation, interviews, and documentation. The analysis was carried out by miles and huberman techniques. Research results include: 1). The role of homeroom is that it is very much needed even very important in terms of the management of children with special needs. As the right of the homeroom teacher in managing his students in the classroom, his roles include making plans for implementing learning, designing syllabi, media, and
\end{abstract}




$\begin{array}{ll}\text { Volume } & : 06 \\ \text { Nomor } & : 02 \\ \text { Bulan } & : \text { Mei } \\ \text { Tahun } & : 2020 \\ \text { http } & : / / \text { jurnal.pps.ung.ac.id/index.php/AKSARA/index }\end{array}$

modifying curriculum. 2). Homerooms in the management of special needs children are homeroom teachers and special mentoring teachers always accompany regular students and children with special needs during the learning process until the learning is complete, the classroom atmosphere is always made fun sometimes there are also students who are bored so the teacher becomes more active in looking after. The homeroom teacher understands that management is not only theoretically using his own instincts. Obstacles are the lack of skills in exploring children with special needs because education personnel are not graduates of schools for children with special needs. Management of children with special needs carried out by teachers at SDN 1 Banda Aceh, management can be done well, as evidenced by students always playing an active role in learning and students are able to carry out evaluations conducted by the teacher. And for the next researcher, hopefully it can study more deeply about the management of homeroom teachers and special teachers in managing and handling children with special needs $(\mathrm{ABK})$ and the factors that influence barriers to better complement and refine this research.

Keywords: The Role of Class Guardians, Management, Children with Special Needs (ABK).

\section{PENDAHULUAN}

Manusia pada dasarnya sangat mementingkan pendidikan karena berpengaruh sangat kuat pada kelangsungan hidupnya. Sebuah bangsapun dapat dinilai dari tingkat pendidikan masyarakatnya. Dijelaskan sebagai penilai karena suatu informasi yang akan disampaikan pada pihak-pihak yang akan datang (generasi seterusnya). Hal inilah yang mengharuskan generasi selanjutnya paham bahwa pendidikan yang ditempuh mereka akan dapat membuat maju tanah kelahiran mereka. Ki HAJAR Dewantara pernah menjelaskan bahwa sebuah pendidikan didapatkan untuk meningkatkan kesadaran social serta rasa tanggung jawab yang didalamnya tercantum penguatan karakter, penguatan pikiran, serta penguatan fisik.

Sejak diberlakukannya UU No.20/2003 tentang Sistem Pendidikan Nasional luar biasa yang diubah menjadi satu nama singkat yaitu pendidikan khusus. Ini diberlakukan pada anak didik yang punya fisik berbeda, emosional terganggu, mental yang tidak sempurna, serta beberapa bakat istimewa lainnya. di tahun 2013, Kemendikbud telah meresmikan bahwa "Wajib Belajar ditempuh selama 12 Tahun'. Dan ditahun 2020 ini, Kemendikbud menetapkan titik target tertinggi bahwa masyarakat setidaknya harus lulus Sekolah Menengah Atas (SMA).

Di tahun 2007 muncul beberapa pemicu yang mendorong tatanan dalam pendidikan inklunsif. Saat memasuki bulan maret, konvensi ini semakin jelas dengan isi" Diwajibkan bagi setiap negara untuk melaksanakan sistem inkulunsif dinegaranya'. Diberlakukannya hal ini dengan harapan bahwa masyarakat akan lebih berpartisipasi dalam meningkatkan mutu pendidikan di negaranya.

Semenjak saat itu, banyak sekolah yang sudah menyetujui dan menyatakan bahwa sekolah mereka telah menjadi sekolah inklunsif, namun tetap saja pelaksanaan yang mereka lakukan masih sama seperti pelaksanaan sistem sekolah yang sebelumnya. Hal ini bahkan lebih buru karena makin sering ditemukannya kesalahan praktek dalam pelaksanaannya dengan alasan sesuai dengan isi perintah pemerintah. Tentu saja ini membuat kebijakan internal sekolah semakin rumit ditambah kurikulum yang tidak mudah. Inilah yang menjelaskan bahwa pelaksanaan yang saat itu diterapkan membuat muncul beberapa masalah dan masalah tersebut sangat kompleks hingga akan sangat susah untuk diatasi oleh satu pihak. Karena ini dibutuhkan kerelaan dari beberapa pihak agar pelaksanaan pendidikan inklusif ini dapat berjalan sesuai dengan arahan yang sebenarnya. 


$\begin{array}{ll}\text { Volume } & : 06 \\ \text { Nomor } & : 02 \\ \text { Bulan } & : \text { Mei } \\ \text { Tahun } & : 2020 \\ \text { http } & : / / \text { ejurnal.pps.ung.ac.id/index.php/AKSARA/index }\end{array}$

Pendidikan inklusif yang telah diterapkan disekolah semestinya merujuk kepada manajemen pendidikan inklusif. Sebuah sekolah akan diselenggarakan jika terdapat beberapa acuan dasar yang telah ditetapkan pemerintah. Hal ini bisa seperti sebuah kelulusan yang harus sesuai dengan standar, isi materi yang dibagikan dalam pengajaran sesuai standar, pelaksanaan sekolah dilakukan sesuai standar, pengelolaan sekolah dilakukan sesuai standar, tenaga pendidikan yang dipilih harus melewati standar, disediakannya sarana serta prasarana yang melewati standar, pengaturan biaya yang melewati standar, serta poin yang dijadikan indikator penilaian sebuah sistem yang dimasukkan dalam kategori standar. Karena inilah diwajibkan untuk memberikan pedoman yang akan mengarahkan bagaimana seharusnya pelaksanaan dari pendidikan inklusif ini.

Permasalahan lainnya terkait dengan penerimaan Anak Berkebutuhan Khusus yang sudah ditunjuk untuk menjadi sekolah inklusif. SK secarah sah telah dikeluarkan oleh Dinas Pendidikan Kota Banda Aceh dan memberikan perintah pada Sembilan sekolah dasar untuk menerima anak didik yang diketahui atau tercatat sebagai anak yang berkebutuhan khusus, akan tetapi penolakan secara menyeluruh dilakukan oleh pihak sekolah karena tidak adanya guru pengajar khusus.

Untuk menghadapi persoalan-persoalan yang muncul, diputuskanlah bahwa pemerintah akan membangun sekolah bagi anak berkebutuhan khusus dan dinamakan sekolah inklusif. Sekolah inklusif dapat menjadi wadah guna mengembangkan potensi serta bakat yang terpendam dari lahir serta mendapat kesempatan untuk merasakan tingkat pendidikan yang sama dengan anak lainnya mulai dari SD, SMP, SMA disekolah umum seperti halnya anak normal. Komitmen akan terus ditingkatkan untuk bidang pendidikan dengan memberikan kesetaraan yang sama antara anak pada umumnya dengan anak yang istimewa. Hal inilah yang harus dibentuk beberapa program, khusus agar pelaksanaan pendidikannya dapat berjalan dengan baik.

Kegiatan belajar mengajar dikelas inklusif akan disamakan dengan aktivitas yang dilakukan oleh kelas regular pada umunya. Namun harus disadari poin utamanya bahwa anak didik yang didalam kelas punya kelainan dari segi emosinal, intelektual, serta fisiknya yang memungkinan sedikit penanganan yang berbeda. Hal ini dijelaskan bahwa strategi yang dipilih untuk pengajaran harus disesuaikan dengan metode dan media yang mudah dipahami oleh anak didik yang ada dikelas.

SDN 1 Banda Aceh beralamat di Jl. Prof. A. Majid Ibrahim I No. 23 Banda Aceh, Merduati, Kec. Kuta Raja, Kota Banda Aceh, dengan kepala sekolah Bapak Ramli S.Pd., M.Pd, dan wakil kepala sekolah Ibu Ellia Sari, S.Pd, dengan jumlah guru 23 orang, dan jumlah siswa 334 orang (ABK 3 orang), dikelas II/a 1 siswa, II/b 1 siswa, dan II/c 1 siswa. Dan jumlah siswi 279 orang (ABK 3 orang) dikelas II/a 1 siswi, II/b 1 siswi, dan II/c 1 siswi.

SDN 1 Banda Aceh ini sudah terakreditasi A. Disekolah ini terdapat Anak Berkebutuhan Khusus, tetapi tidak ditempatkan diruangan khusus melainkan belajar bersama anak lain (normal) dikelas reguler dengan kurikulum yang bersamaan, namun dalam waktuwaktu tertentu ditarik dari kelas reguler keruang sumber untuk belajar dengan guru pendamping khusus.

Berdasarkan hal diatas, maka penulis tertarik untuk menelaah tentang peran didalam pengelolaan pendidikan inklusif Anak Berkebutuhan Khusus (ABK) yang telah diterapkan dibeberapa sekolah dasar negeri dikota Banda Aceh, analisa spesifik yang telah diterapkan disekolah meliputi perencanaan, pelaksanaan, pengawasan dan pengevaluasian. Oleh karena itu, penulis melakukan penelitian dengan mengangkat judul: "Peran Wali Kelas dalam Pengelolaan Anak Berkebutuhan Khusus (ABK) di SDN 1 Banda Aceh". Penelitian ini penting untuk diteliti berkaitan dengan peraturan pemerintah yang mewajibkan seluruh 


$\begin{array}{ll}\text { Volume } & : 06 \\ \text { Nomor } & : 02 \\ \text { Bulan } & : \text { Mei } \\ \text { Tahun } & : 2020 \\ \text { http } & : / / \text { ejurnal.pps.ung.ac.id/index.php/AKSARA/index }\end{array}$

sekolah untuk menerima anak didik termasuk Anak Berkebutuhan Khusus tanpa memberikan penolakan. Oleh karena itu wali kelas harus memiliki kesiapan dalam menangani Anak Berkebutuhan Khusus agar pendidikan untuk Anak Berkebutuhan Khusus dapat diakomodasi dengan lebih baik.

\section{KAJIAN PUSTAKA}

\section{Landasan Teori Tentang Peran Wali Kelas}

Wali kelas punya peran penting dalam memerhaikan setiap perkembangan anak didiknya. Ini diungkapkan oleh Doni Koesoema dengan memberikan sedikit penjelasan bahwa kemajuan serta keadaan kelas tergantung dari bagaimana wali kelas memasuki kebiasaan anak didiknya. Hal inilah yang menjadikan seorang wali kelas menjadi penanggung jawab secara penuh bagi anak didiknya selama di sekolah. Penilaian yang dipakai untuk menentukan seorang wali kelas mampu atau tidak dilihat dari cara ia mengarahkan komunitas kelasnya. Akan lebih baik jika wali kelas ialah seorang guru mata pelajaran tertentu agar ia dapat memberikan pengajaran lebih mengenai bidang studinya di kelasnya. Ini sama halnya sebagai kepala keluarga yang harus mampu memahami setiap karakter dari anak-anaknya serta mengayomi agar anaknya tidak salah jalan. (Usman, 2012).

Karena inilah guru harus mampu menyadari bahwa ia punya peran dan fokus yang sama, namun di bidang yang berbeda yaitu bidang pendidikan.

Kepala sekolah memilih seseorang yang telah melewati pedoman standar tertentu untuk bertanggung jawab penuh pada anak didiknya. Ini sama kesediaan dari guru dalam membatu kepala sekolah melaksanakan sistem tatanan sekolah. Wali kelas inilah yang diberi arahan oleh kepala sekolah mengenai cara yang tepat untuk mendisiplikan seorang anak didik serta peran andil yang harus dilakukannya dalam menjaga sikap, komunikasi, serta kepercayaan anak didiknya. Dalam hal ini, kita sadar sepenuhnya bahwa beban yang diberikan pada wali kelas ialah beban yang disesuaikan dengan cara ia mengampu. Hal ini dimasukkan sebagai penanggung jawab yang harus dilakukan dalam pengajaran (Koesoema, 2007).

Laurence dan Jonathan pernah menjelaskan bahwa guru yang telah terpilih sebagai wali kelas ialah seorang guru yang diakui kemampuan serta sikapnya dalam mengarahkan dan mendukung pelaksanaan sekolah untuk lebih baik lagi. Jean dan Morris juga menjelaskan bahwa pengalaman yang didapatkan oleh seorang guru yang bertugas sebagai wali kelas ialah sebuah pengalaman yang akan meningkatnya kemampuannya dibatas tertinggi.

Di tahun 2015 telah dikeluarkan sebuah UUGD yang dapat dilihat lebih jelas di Nomor 12 pasal 1 bahwa seorang guru mempunyai kewajiban sebagai tenaga pendidik, memberi pengajaran, mengarahkan, serta memberikan bimbingan bagi anak didiknya. Hal ini diberlakukan pada sekolah dasar, sekolah menengah, serta pendidikan formal lainnya.

Pemilihan seorang guru untuk menjadi wali kelas harus melewati beberapa standar. Adapun standar yang dimaksud berupa susunan program yang akan dirancang guna mengelola anak didiknya agar dapat sampai ke tujuan akhir sebuah pendidikan.

\section{Kesiapan Wali Kelas dalam Menghadapi Pendidikan Inklusif ABK}

Belakang ini sudah diberitahukan oleh pemerintah bahwa seluruh tenaga pendidik yang bertugas di sekolah regular wajib untuk mulai mempelajari ketrampilan dasar yang diterapkan di sekolah luar biasa. Ini ditekankan karena seorang tenaga pendidik bukan hanya memiliki anak didik yang biasa, namun juga akan memiliki anak didik yang berkebutuhan istimewa. Namun tentu kita telah mengetahui bahwa tenaga pendidik yang diberikan tugas mengajar anak berkebutuhan khusus harus lebih bisa mengayomi anak didiknya dengan mempelajari beberapa strategi yang tidak bisa diajarkan seperti biasa di kelas regular. 


$\begin{array}{ll}\text { Volume } & : 06 \\ \text { Nomor } & : 02 \\ \text { Bulan } & : \text { Mei } \\ \text { Tahun } & : 2020 \\ \text { http } & : / / \text { jurnal.pps.ung.ac.id/index.php/AKSARA/index }\end{array}$

Pendidikan inklusif akan berhasil jika tenaga pendidiknya dengan rela dan siap untuk menerima bahwa ia diberikan tugas yang cukup berat sebagai pengayom dari anak-anak yang terlahir istimewa. Karena jika tenaga pendidik mampu melakukan hal itu, makan pendidikan inklusif ini akan berhasil. Selain itu diperlukan untuk melakuka setiap kegiatan dengan menyusupkan sedikit latihan-latihan hingga anak-anak yang istimewa merasa bahwa ia mampu melakukan aktivitas yang dilakukan bersama gurunya di dalam kelas.

Menurut Djamarah Syaiful Bahri menuturkan bahwa cirri khas yang ditampilkan oleh seorang anak akan berbeda sesuai dengan kepribadiannya dan lingkungan tempat tinggalnya. Inilah yang bisa dilakukan dan diperhatikan seorang guru seblum mendekati dan berteman dengan anak-anak istimewa tersebut. Jika seorang guru mengerti bahwa karakteristik anak didiknya berbeda, ini akan memudahkan dan menimbulkan rasa percaya diri anak didik hingga merasa nyaman dan terbantu dengan gurunya. Dari sini kita sudah tahu bahwa hal ini akan membuat kegiatan belajar dapat berjalan dengan efektif dan efisiensi.

Apabila eseorang telah merasa ia siap untuk berdiskusi dan melakukan kegiatan mengajar di sekolah dapat dinilai dari indikator kesukaannya, pengembangan minatnya, keingintahuannya, serta tujuannya yang sejalan dengan niat mulianya untuk mengabdi. Guru akan dinilai siap jika ia telah selesai dibina dan nilai yang didapatkannya dalam kompetensi melebihi nilai standar kompetensi penilaian. Dijelaskan disini bahwa pembinaan berarti pemberian profesi yang dilengkapi adanya sertifikasi, pelatihan-pelatihan, serta penataran..

Dilakukannya hal ini agar guru tersebut merasa bahwa dirinya mampu dan berusaha untuk memahami permasalahan anak didiknya yang berbeda dari murid biasanya. Dalam hal ini perlu diberikan juga guru pembimbing agar dapat menjadi tempat diskusi wali kelas sebelum akhirnya memutuskan sebuah rencana yang akan dilakukan pada anak didiknya yang istimewa. Dalam hal ini, dua tenaga pendidikan harus saling bekerjasama dan mendukung untuk menujukkan keprofesionalisme mereka didalam menghadapi dunia kerja para guru pada umumnya.

\section{Landasan Teori Tentang Siswa Berkebutuhan Khusus}

Menurut Sapon-Shevin mengatakan bahwa murid merupakan anak didik yang telah terdaftar secara resmi disebuah sekolah yang diawasi oleh dinas pendidikan. Anak didik harus dapat dibina dengan baik dan punya budi pekerti agar dapat berguna dan menolong masyarakat. Fuchs memberikan sebuah penjelasan mengenai anak-anak istimewa yang punya kebutuhan lebih harus dapat diberikan haknya yang sama dengan hambatan agar dijauhkan dari keterlambatan dalam menerima perkembangan zaman serta teknologi yang terus berubah. Dikatakan sebagai siswa inklusif jika anak didik istimewa tersebut berada di ruang belajar yang sama dengan anak didik lain lainnya dan tempatnya itu di kelas regular. Anak istimewa itu dapat dijelaskan sebagai anak yang tidak dapat mendegar dengan baik, atau anak yang yang autis.

Simpulan yang ditarik yaitu anak yang istimewa belajar hal yang sama dengan anakanak pada umumnya namun diberikan sedikit perbedaan seperti pelayanan yang sesuai dengan kekurangannya disebut sebagai sisswa inklusif. Pada dasarnya, siswa-siswa ini akan merasa bahwa dirinya tidak berbeda dengan siswa lainnya dan ia tidak merasa diabaikan. Dalam hal ini, anak yang istimewa dimasukkan dalam kategori anak yang pintarnya melebihi rata-rata dan anak yang cenderung tidak pintar dan lamban. (Iswari, 2007). Menurut Kosasih dalam buku Sitriah Salim dijelaskan bahwa gangguan yang datang pada anak seperti kekurangan pada fisik, mentalnya yang kurang, punya emosi yang tidak wajar atau bahkan tidak punya emosi digolongkan pada anak yang berkebutuhan khusus. Jadi dapat kita simpulkan lebih dalam bahwa anak berkebutuhan khusus bukan hanya anak yang mempunyai 


$\begin{array}{ll}\text { Volume } & : 06 \\ \text { Nomor } & : 02 \\ \text { Bulan } & : \text { Mei } \\ \text { Tahun } & : 2020 \\ \text { http } & : / / \text { jurnal.pps.ung.ac.id/index.php/AKSARA/index }\end{array}$

kekurangan, namun juga anak yang punya bakat-bakat terpendam namun tidak wajar diusianya. Hal inilah yang menjelaskan bahwa ia dikategorikan sebagai kebutuhan khusus.

Inilah yang harus lebih diperhatikan, karena pada umumnya anak-anak istimewa ini lebih membutuhkan berbagai perhatian dimana itu akan membantu tumbuh kembang otak dan mentalnya. Maka dari itu pihak sekolah harus selalu menyediakan beberapa pelayanan yang sesuai dengan apa yang dibutuhkan oleh mereka. Perbedaan yang mencolok ini harus dapat dipahami guru agar anak-anak istimewa ini tidak merasa rendah diri.

Anak berkebutuhan khusus dapat di klarifikasi atas dua golongan yang punya sifat berbeda. Adapun sifat itu akan diuraikan dalam poin-poin berikut yaitu:

a. Dikatakan sebagai anak yang berkebutuhan khusus namun punya sifat yang sementara apabila anak didik tersebut terganggu tumbuh kembangkan karena ada kejadian di masalalu dan masih terbayang dengan kejadian tersebut. Ini dapat digambarkan dengan trauma. Pada umunya ini biasanya didapatkan karena dukungan faktor eksternal.

b. Dikatakan sebagai anak berkebutuhan khusus dan punya sifat tetap jika anak didik tersebut terganggu masa tumbuh dan kembangnya karena ada cacat yang disebabkan kecelakaan ataupun dari lahir. Ini dicontohkan sebagai anak didik yang mengalami kebutaan setelah kecelakaan.

Jika hanya terfokus pada kekurangan yang dimiliki oleh anak-anak yang berkebutuhan berbeda, kita tidak akan ingat bahwa mereka yang berbeda juga punya hak sebagai warga negara untuk memperoleh kesempatan dalam belajar seperti anak normal pada umumnya. Kekurangan yang mereka punya bukan hal yang harus menjadikan alasan kuat bahwa mereka tidak punya hak atas apapun sebagai warga negara. Karena inilah Pemerintah seharusnya lebih mengerti bahwa penanganan yang berbeda merupa solusi yang tepat bagi mereka. Karena kita telah menyadari bahwa anak berkebutuhan khusus tersebut tidak punya beberapa hal seperti anak-anak pada umumnya, diperlukan sebuah metode serta strategi yang tepat agar anak didik tersebut mampu menerima pelajaran yang diberikan. Sekolah yang diberikan pada mereka akan memberikan perbaikan-perbaikan baik yang akan timbul di diri anak didiknya. Hal ini bisa seperti perbaikan mental atau perbaikan komunikasi yang sesuai. Dari sini dapat kita entukan hal yang menjadi fokus yaitu memberikan pendidikan sebaik mungkin pada mereka tanpa pernah melabeli mereka sebagai orang yang tidak sanggup atau kekurangan.

\section{Landasan Teori Tentang Pengelolaan Anak Berkebutuhan Khusus}

Di dalam sebuah buku Teorical Considerations telah dijelaskan pendapat dari C.A Anderson serta M.J. Bowman bahwa sebuah perencanaan yang telah disiapkan jauh-jauh hari harus dapat memudahkan putusan-putusan yang dilakukan dimasa depan. Hal ini berkaitan dengan rancangan yang telah dituliskan dengan beberapa persiapan yang akan disusun mulai dari awal hingga berakhirnya perancangan tersebut. Inilah penjelasan inti terkait dengan planning yang berfokus.

Sistem yang harus direncanakan dari anak yang membutuhkan beberapa hal karena kekurangan yang dimilikinya harus dapat dikelola dengan mengikuti beberapa perkembangan yang menjelaskan masalah inklusif ini. Hal ini dapat dipengaruhi dari beberapa faktor, mulai dari asal sekolah tenaga pendidik sebelumnya dengan cara mengajar yang diterapkan aat dilakukan kegiatan belajar mengajar.

Adapun beberapa rencana yang harus dipersiapkan untuk anak yang mempunyai kekurangan yaitu:

a. Kurikulum (Bahan Ajar) 


$\begin{array}{ll}\text { Volume } & : 06 \\ \text { Nomor } & : 02 \\ \text { Bulan } & : \text { Mei } \\ \text { Tahun } & : 2020 \\ \text { http } & : / / \text { ejurnal.pps.ung.ac.id/index.php/AKSARA/index }\end{array}$

Pada dasarnya sebelum dilakukan kegiatan belajar, kita harus paham bahwa kurikulum yang akan diajarkan telah tersistem dengan baik guna mewujudkan sebuah pendidikan yang sempurna. Hal ini terjadi karena pembentukan kurikulum merupakan langkah dasar dalam pelaksanaan. Tentu ini berbeda dengan sumber daya manusia yang harus dijalankan dengan ketentuan-ketentuan yang telah ditetapkan sebelumnya. Untuk itu, belajar bukan hanya soal siswa yang menerima pelajaran. Tapijuga soal bagaimana cara guru menyampaikan materi, serta bagaimana susunan materi yang tepat agar dapat diterima dengan baik oleh anak0anak istimewa ini.

Kurikulum yang telah selesai di modifikasi dari kurikulum regular biasanya akan dirancang dan disusun sesuai dengan sistem keharusan pola pikir anak. Ini dapat dilihat dari perolehan yang menjelaskan beberapa ciri khas yang mendukung.

b. Tenaga Pendidik (Guru/wali kelas)

Kegiatan belajar mengajar dapat berjalan dengan baik jika gurunya dapat mengontrol suasana didalam kelas selama diadakannya kegiatan belajar. Karena inilah sangat pentingnya guru-guru yang menguasai bidang pelajaran tertentu. Dari sini dapat kita simpulkan bahwa guru juga menjadi faktor penentu dari berhasilnya kegiatan belajar mengajar.

\section{Landasan Kelas Bagi Anak Berkebutuhan Khusus}

Surat An Nisa ayat 9

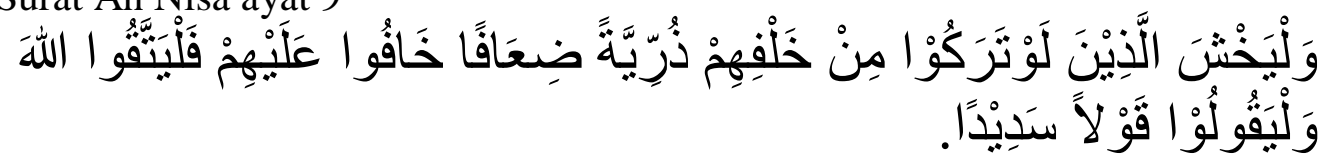

"Sebaik-baik manusia adalah manusia yang tidak meninggalkan anak-anak yang masuk dalam golongan lemah hanya karena ketakutan mereka yang takut tidak sejahtera. Sesungguhnya Allah menyayangi hamba-hambanya yang bertakwa kepadanya dengan cara menolong sesamanya dan bekata benar.'

Dapat kita lihat dari penjelasan ayat diatas bahwa Allah akan sangat meridhoi manusia-manusia bertakwa yang menolong anak didiknya yang istimewa. Sebuah pekerjaan akan sia-sia jika Allah tidak memberi izin. Jadi manusia tidak seharusnya takut tidak sejahtera, karena sepantasnya Allah akan memberikan hal yang lebih baik pada umatnya yang beriman.

Pancasila merupakan sebuah pilar yang mengharuskan bahwasetiap anak di Indonesia harus merasakan pendidikan yang sama tanpa ada perbedaan. Ini dijelaskan Mulyono berdasarkan filosofisnya tanpa membedakan anak yang kaya dengan yang miskin, serta yang normal dan berkebutuhan khusu. Ini masuk dalam pondasi dasar kita yiatu Bhineka Tunggal Ika. Ini dijelaskan dalam manusia yang serata, tanpa diberlakukannya srata-srata tertentu.

Jika dibahas Bhineka Tunggal Ika secara vertikal maka sama artinya kita akan membahas bahwa manusia yang satu tidak sama dengan manusia yang satunya lagi. Ini dijelaskan dengan perbedaan jabatan antara dua manusia, keadaan keuangan dua manusia, serta kemampuan serta kecerdasan dua manusia lainnya. sedangkan dalam sisi horizontal dijelaskan dengan tidak samanya ras dan suku, tidak samanya bahasa serta budaya, juga tidak samanya agama dan aturan yang diatut di daerah tertentu.

Dalam hal ini dimasukkan dalam sisi horizontal karena memberikan dua kelompok yaitu manusia yang normal pada umumnya dengan manusia yang punya kekurangan (disamaratakan dengan tidak samanya suku dan budaya). Ini tentu menjadi hal yang lebih baik dijauhi dibanding dilaksanakan. Karena pada dasarnya manusia harus saling tolong menolong dalam kebaikan dan mampu menjunjung tinggi toleransi sebagaimana ajaran yang 


$\begin{array}{ll}\text { Volume } & : 06 \\ \text { Nomor } & : 02 \\ \text { Bulan } & : \text { Mei } \\ \text { Tahun } & : 2020 \\ \text { http } & : / / \text { jurnal.pps.ung.ac.id/index.php/AKSARA/index }\end{array}$

kita dapatnya mulai dari SD hingga tamat SMA. Dalam hal ini, perbedaan ini mencoret arti dari Bhineka Tunggal Ika yang selalu kita jadikan pedoma bernegara.

\section{Prinsip-Prinsip Pengelolaan Kelas Anak Berkebutuhan Khusus}

Kita telah mengetahui bahwa akan lebih susah bagi guru untuk mengajar dikelas yang anak didiknya merupakan anak didik yang istimewa. Karena itu diberikan beberapa pendekatan yang harus digunakan serta diharapkan dapat membantu guru untuk lebih mudah dalam melaksanakan proses belajarnya. Dalam hal ini, guru harus memahami bahwa anakanak didiknya sadar bahwa ini difokuskan pada dirinya. Adapun hal ini berkisar antara:

1) Tidak menyalahkan orang lain dengan keadaannya saat ini.

2) Mau menerima keadaan lingkungannya dan mulai berinteraksi dengan temanteman barunya.

3) Percaya bahwa ia masih mampu untuk berjuang kembali.

4) Ia punya sesuatu yang istimewa yang tidak dimiliki oleh orang lain.

5) Ia sadar bahwa ia punya hak sebagai warga yang sah di Indonesia.

Selain hal itu, ada tujuan lain yaitu pengumpulan dan penentuan yang dikhususkan pada anak didik berkebutuhan khusus agar ia mendapatkan pertolongan serta pelajaran yang tepat sesuai dengan kondisi yang ia hadapi.

\section{METODE PENELITIAN}

Penelitian ini dilaksanakan dengan metode deskriptif dan dianalisa dengan pendekatan kualitatif, dimana peneliti berusaha untuk menyelidiki dan mengungkapkan, serta memaparkan data alami sesuai dengan apa yang terjadi dilapangan.

\section{HASIL PENELITIAN}

\section{Peran wali kelas dalam pengelolaan Anak Berkebutuhan Khusus (ABK) di SDN 1 Banda Aceh}

Hasil penelitian menunjukkan bahwa wali kelas dalam menjalankan pengelolaannya di sekolah sudah sangat baik dalam berperan. Wali kelas sangat berkompeten dalam bidangnya dan bertanggungjawab terhadap tugas-tugasnya.

Wali kelas juga memiliki peran penting dalam meningkatkan pengelolaan di dalam kelas. Segala sesuatu membutuhkan proses, demikian pula dengan pengelolaan dan kesiapan akan terbentuk perlahan seiring dengan perkembangan seseorang dengan laju sesuai dengan tingkat perkembangan masing-masing. Sehingga kesiapan wali kelas dalam melaksanakan sesuatu akan lebih tinggi jika ia memiliki pengalaman akan hal tersebut. Sehingga, penting bagi wali kelas untuk memahami pengertian dari pengelolaan dan prinsip-prinsip yang terkandung di dalamnya. Dengan pemahaman tersebut, diharapkan seseorang dapat lebih meningkatkan kesiapannya dalam melaksanakan apapun secara profesional.

Subjek guru yang dibicarakan dalam penelitian ini adalah wali kelas dan guru pembimbing khusus. Berdasarkan hasil penelitian dan pengertian guru yang telah dijabarkan sebelumnya, dapat disimpulkan bahwa wali kelas adalah orang dewasa yang memiliki kemampuan berdasarkan program pendidikan yang telah didapatkan untuk mengelola kelas dalam rangka memberikan ilmu pengetahuan kepada anak didik agar memiliki keterampilan dan mencapai tingkat kedewasaan. Sedangkan guru pembimbing khusus adalah seorang guru yang memiliki kemampuan dalam menangani anak berkebutuhan khusus maupun anak luar biasa yang ditugaskan mengajar di SDN 1 Banda Aceh maupun sebagai tenaga yang diperbantukan untuk guru-guru kelas di sekolah inklusif dalam rangka menangani dan 


$\begin{array}{ll}\text { Volume } & : 06 \\ \text { Nomor } & : 02 \\ \text { Bulan } & : \text { Mei } \\ \text { Tahun } & : 2020 \\ \text { http } & : / / \text { jurnal.pps.ung.ac.id/index.php/AKSARA/index }\end{array}$

mengelola anak berkebutuhan khusus yang ada di kelas. Tenaga kependidikan merupakan ujung tombak dalam melaksanakan perubahan. Oleh karena itu guru sebagai orang yang langsung berhadapan dengan anak didik, orang tua, dan masyarakat, harus mampu memberikan layanan pendidikan kepada semua anak tanpa terkecuali secara ramah dan profesional.

Wali kelas di sekolah dasar selain mempunyai tugas dan tanggungjawab terhadap anak didiknya, juga bertugas untuk menyelenggarakan pelayanan bimbingan bagi seluruh anak didik di kelas yang menjadi tanggungjawabnya. Seorang wali kelas hendaknya mampu mengembangkan pribadi anak didik dan segenap potensi yang dimiliki anak agar dapat berkembang secara optimal. Untuk itu diperlukan strategi-strategi khusus yang harus dilaksanakan oleh guru. Beberapa strategi yang dapat dilakukan dalam menangani anak berkebutuhan khusus dan anak reguler dalam kelas inklusif diantaranya :

a. Kumpulkan sebanyak mungkin informasi mengenai setiap anak.

b. Sesuaikan cara mengajar dengan karakteristik dan kebutuhan masingmasing anak, baik untuk anak berkebutuhan khusus maupun anak reguler.

c. Bersikap fleksibel ketika mengajar.

d. Identifikasi dan ajarkan pengetahuan dan keterampilan yang mungkin belum diperoleh anak karena hambatan tertentu.

e. Lakukan konsultasi dan kerjasama dengan spesialis.

f. Komunikasikan segalanya dengan orang tua secara teratur.

g. Libatkan anak didik dalam pembuatan rencana dan pengambilan keputusan.

h. Tetaplah buka mata terhadap anak didik yang mungkin memenuhi kualifikasi untuk mendapatkan pelayanan khusus.

Kompetensi-kompetensi di atas dapat menunjukkan bahwa menjadi seorang wali kelas di kelas inklusif bukanlah hal yang mudah. Namun bukan berarti hal tersebut tidak bisa dilakukan dengan baik. Disinilah kesiapan dalam mengelola dan menghadapi pendidikan inklusif menjadi sangat penting untuk dimiliki seluruh tenaga kependidikan yang terlibat di dalamnya. Banyak strategi yang dapat digunakan guru dalam menangani dan mengelola anak berkebutuhan khusus. Namun, perlu diingat bahwa tidak ada strategi yang benar-benar tepat untuk mengelola semua anak berkebutuhan khusus. Sebagai seorang wali kelas, hendaknya dapat memahami karakteristik anak berkebutuhan khusus, baik itu kemampuan maupun ketidakmampuannya.

Kemudian pilihlah strategi yang tepat untuk menangani anak berkebutuhan khusus sesuai dengan karakteristik dan kebutuhan masing-masing anak. Jadi, strategi yang sama belum tentu tepat untuk semua anak berkebutuhan khusus.

\section{Hambatan wali kelas dalam pengelolaan anak berkebutuhan khusus (ABK) di SDN 1 Banda Aceh}

Dari hasil penelitian dan pendapat di atas bahwa pada dasarnya anak berkebutuhan khusus memiliki karakteristik dan kebutuhan masing-masing yang mungkin memiliki hambatan dalam hal tertentu. Oleh karena itu, wali kelas bertanggung jawab untuk mengumpulkan informasi tentang kekhususan anak dan mengajarkan apa yang belum dikuasai anak. Sehingga sebuah strategi tidak bisa dipaksakan untuk anak berkebutuhan khusus. Wali kelas harus mampu memilih program pembelajaran dan memberikan pelayanan khusus untuk anak berkebutuhan khusus.

Hambatan yaitu kurangnya skill dalam menggali anak berkebutuhan khusus karena tenaga kependidikan bukan lulusan dari sekolah untuk anak berkebutuhan khusus. Pengelolaan anak berkebutuhan khusus yang dilakukan oleh guru di SDN 1 Banda Aceh. 


$\begin{array}{ll}\text { Volume } & : 06 \\ \text { Nomor } & : 02 \\ \text { Bulan } & : \text { Mei } \\ \text { Tahun } & : 2020 \\ \text { http } & : \text { //ejurnal.pps.ung.ac.id/index.php/AKSARA/index }\end{array}$

\section{PENUTUP}

Berdasarkan penelitian yang telah peneliti lakukan dapat disimpulkan bahwasanya: Peran wali kelas di SDN 1 Banda Aceh dalam pengelolaan masih perlu ditingkatkan, dengan upaya-upaya yang telah diprogramkan oleh kepala sekolah. Wali kelas sudah melakukan perannya dengan baik dalam pengelolaan ABK, meskipun masih ada hambatan mengenai lulusan tenaga kependidikan disekolah tersebut. Guru pendamping khusus di SDN 1 Banda Aceh sudah sangat berperan dalam mengelola anak berkebutuhan khusus. Namun yang menjadi hambatan, mereka juga bukanlah lulusan/pendidik untuk ABK. Kepala sekolah di SDN 1 Banda Aceh telah banyak menjalankan program pengelolaan terhadapat wali kelas dan guru pendamping khusus, Namun masih terdapat hambatan dari segi lulusan tenaga pendidik, tetapi peran dalam pengelolaannya tetap dilakukan oleh wali kelas dan guru khusus secara maksimal di SDN 1 Banda Aceh.

\section{DAFTAR PUSTAKA}

Abdur Rozek, (2016). Implementasi Manajemen Pembelajaran bagi Anak Inklusif di MTs Wachid Hasyim Surabaya, Skripsi S-1, Prodi Manajemen Pendidikan Islam, Fakultas Tarbiyah dan Keguruan, Universitas Islam Negeri Sunan Ampel Surabaya.

Adriadi, (2014). Manajemen Inklusif di MAN Maguwoharjo Depok Sleman Yogyakarta, Skripsi S-1, Jurusan Kependidikan Islam, Fakultas Tarbiyah dan Keguruan, Universitas Islam Negeri Sunan Kalijaga Yogyakarta.

Ahmad Rohani, (1991). Pedoman Penyelenggaraan Administrasi Pendidikan Sekolah, Jakarta: Bumi Aksara.

Burhanudin, (1994). Analisis Administrasi Manajemen Dan Kepemimpinan Pendidkan, Jakarta: Bumi Aksara.

Djamarah bahri syaiful. (2010). Guru dan anak didik dalam interaksi edukatif. Jakarta: rineka cipta.

Doni Koesoema A, (2007). Pendidikan Karekter. (Jakarta: Gramedia Widiasarana.

Hega Raka Ardana, (2014). Manajemen Peserta Didik Sekolah Inklusif di Sekolah Menengah Pertama PGRI Kecamatan Kasihan, Skripsi S-1, Jurusan Administrasi Pendidikan Prodi Manajemen Pendidikan, Fakultas Ilmu Pendidikan, Universitas Negeri Yogyakarta.

Ismail SM, (2008). Strategi Pembelajaran Agama Islam Berbasis PAIKEM, Semarang: RaSAIL Media Group.

Jamil Suprihatiningrum, (2013). Guru Profesional. Jogjakarta: Ar- Ruzz Media.

J. David Smith, (2006). Inklusif Sekolah Ramah Untuk Semua, Bandung: Nuansa.

Mega Iswari, (2007). Kecakapan Hidup Bagi Anak Berkebutuhan Khusus.

Jakarta : Direktorat Ketenagaan.

Mohammad Efendi, (2006). Pengantar Psikopedagogik Anak Berkelainan, Jakarta: Bumi Aksara.

Pedoman Penyelenggaraan Pendidikan Terpadu/inklusi, (2004). Buku 1, Mengenal Pendidikan Terpadu, Direktorat Pendidikan Luar Biasa.

Puput Fathurrohman, (2007). Strategi Belajar Mengajar, Bandung: Refika Aditama.

Suharsimi Arikunto, (1996). Pengelolaan Kelas dan Siswa, Jakarta: Raja Grafindo Persada.

Wina Sanjaya, (2007). Strategi Pembelajaran Berorientasi Standar Proses Pendidikan, Jakarta: Prenada Media. 